\title{
Effect of different proportions of brea gum in the functional characteristics of wheat flour starch: impact on the physical quality of bread
}

\author{
Estela Patricia LÓPEZ ${ }^{1}$, Patricia Liliana JIMÉNEZ ${ }^{1}$
}

\begin{abstract}
The aim of this work was to study the changes induced by BG in the behaviour of wheat starch, and observe the influence of these variations on the quality of a basic white bread. The effect of four BG addition levels in the wheat flour functional characteristics (WAI, WSI, and pasting properties) and bread quality (physical parameters, crumb grain structure, moisture and hardness) was investigated. The highest levels of BG (1\% and $2 \%$ ) decreased the peak viscosity, and increased the stability and setback of the flour. This was due to a lower gelatinization of the starch granules, caused by a competition for water between the hydrocolloid and starch. These changes influenced the bread quality. The loaves added with $1 \%$ and $2 \%$ of BG presented smaller alveoli: this resulted in more compact, hard and less airy crumbs. Nevertheless, the moisture of the samples at $1 \%$ and $2 \%$ of added gum was higher than the control bread. However, the incorporation of BG at $0.5 \%$ did not affect the pasting parameters and bread quality, but increased moisture of crumb, so this concentration would be most recommended for baking, since higher humidity could favour the shelf- life of the product.
\end{abstract}

Keywords: brea gum; wheat flour; bread.

Practical Application: In this paper the functionality of a new and still poorly applied hydrocolloid was investigated. Basic results of this study may be useful for the development of other baked products in which the BG can be applied.

\section{Introduction}

Bread is a product with great nutritional value, consumed worldwide (Kurek et al., 2015; Bowles \& Demiate, 2006). In order to improve the bread quality, many additives are used in bakery, and each one has a different effect over the wheat flour behaviour. Non-starch hydrocolloids (named "hydrocolloids" hereafter) are widely used as additives in the food industry, because they are functional for modifying the rheology and texture of aqueous suspensions (Dziezak, 1991). Hydrocolloids induce structural changes in main components of wheat flour systems along breadmaking steps and bread storage (Mandala et al., 2007; Bárcenas \& Rosell, 2005; Guarda et al., 2004; Collar et al., 1999). The presence of hydrocolloids influenced melting, gelatinization, fragmentation, and retrogradation starch processes (BeMiller, 2011; Funami et al., 2008; Funami et al., 2005, Rosell et al., 2001; Armero \& Collar, 1996; Davidou et al., 1996; Dziezak, 1991). These effects were shown to affect pasting properties, dough rheological behaviour (BeMiller, 2011; Rosell et al., 2001; Collar et al., 1999), and bread quality and staling (Mandala et al., 2007; Bárcenas \& Rosell, 2005; Guarda et al., 2004; Collar et al., 1999). Hydrocolloids also affect breadmaking performance and keepability of stored breads (Bárcenas \& Rosell, 2005; Rosell et al., 2001; Armero \& Collar, 1996; Davidou et al., 1996).

Several studies have been carried out showing the potential use of hydrocolloids in wheat breadmaking industry (López et al.,
2013; Škara et al., 2013; Polaki et al., 2010; Mandala et al., 2008; Mandala et al., 2007; Bárcenas \& Rosell, 2005; Guarda et al., 2004; Rosell et al., 2001; Collar et al., 1999; Armero \& Collar, 1996; Davidou et al., 1996), concluding that is evident the useful of gums in breadmaking. Nevertheless, the properties of the hydrocolloids vary in a great extent depending on their origin, chemical structure and the food matrix to which it are added (Guarda et al., 2004; Rojas et al., 1999). However, the bread industry is looking for new alternatives constantly.

The brea gum (BG) is a hydrocolloid with few published applications in foods, but with great potential, given by their chemical and structural similarities with the Arabic gum (De Pinto et al., 1993; Cerezo et al., 1969). It is a hydrocolloid obtained as phloematic exudate of Cercidium praecox. The genus Cercidium belongs to Leguminosae family. With their extensive root system, brea trees can be found in semi-arid regions of Argentine. Brea trees grow scattered in the wild, and gum from these untended trees is collected manually by native people (Bertuzzi et al., 2012). The exudates gum is obtained from superficial incisions made in the branches and tree trunk. After some weeks, gum is manually collected as partially dried tears. The BG is amber colour; it has semi-liquid consistency and faintly sweet flavour. It is highly soluble in water $\left(28 \%\right.$ at $\left.25^{\circ} \mathrm{C}\right)$ (Bertuzzi et al., 2012). Solutions are homogeneous and present 
acid character $(\mathrm{pH}=4)$. Hence, $\mathrm{BG}$ could be a suitable candidate for incorporation as stabilizing, emulsifying and thickening additive in food formulation (Bertuzzi et al., 2012).

Brea gum has been traditionally used as a 'woodland candy' by countryside people since pre-Colombian times, without producing harmful consequences. von Müller et al. (2009), reported a toxicological evaluation of BG in mice. The results suggest that feeding mice with BG at levels up to $5 \%$, do not exert any toxicological effects, supporting its potential use as a food additive for human consumption.

To date, no research has been focused on studying the influence of the brea gum in the behaviour of wheat starch as a fundamental component of bread, and how these changes impact on the final quality of wheat bread.

For these reasons, this research intends to provide significant results to the scientific community and the food industry as well as being a contribution for that the BG, recently incorporated into the Argentine Food Code, can be also considered by international legislations.

The aim of this work was to study the changes induced by brea gum in the behaviour of wheat starch, and observe the influence of these variations on the quality of white bread.

\section{Materials and methods}

\subsection{Materials}

Wheat flour (WF) suitable for bread making (Molinos Río de la Plata S.A., Buenos Aires, Argentina) was used for producing the bread samples. It had an average extraction rate of $78-79 \%$ according to the manufacturer, $0.71 \mathrm{~g} / 100 \mathrm{~g} \pm 0.03$ (dry basis) mineral matters, $11.80 \mathrm{~g} / 100 \mathrm{~g} \pm 0.06$ for proteins and a wet gluten content of $24.33 \% \pm 0.04$. Its moisture and starch content was $10.00 \mathrm{~g} / 100 \mathrm{~g} \pm 0.13$ and $75.69 \mathrm{~g} / 100 \mathrm{~g} \pm 1.56$ respectively. Compressed yeast (Dánica Argentina S.A., Buenos Aires, Argentina), defatted milk powder (Ilolay, Williner S.A., Santa Fe, Argentina), and salt (Industrias Químicas y Mineras Timbo S.A., Buenos Aires, Argentina) were purchased from local markets.

The brea gum (BG) exudate from the plant in the form of small drops or tears, was collected and provided by indigenous communities from Chaco Salteño (Argentina). The purification process included the steps of grinding, dissolution, decantation, filtration and drying in oven at temperatures below $40^{\circ} \mathrm{C}$, then grinding to fine powder (mesh $80-0.173 \mathrm{~mm}$ ASTM). This hydrocolloid had $13.50 \pm 0.50 \mathrm{~g} / 100 \mathrm{~g}$ of moisture, $3.80 \pm 0.30 \mathrm{~g} / 100 \mathrm{~g}$ of mineral maters and $5.90 \pm 0.20 \mathrm{~g} / 100 \mathrm{~g}$ of protein. Polysaccharide content averaged $76.80 \mathrm{~g} / 100 \mathrm{~g}$.

The BG proportions used in this study were $0.50 \%, 1.00 \%$ and $2.00 \%$ of $B G \mathrm{w} / \mathrm{w}$ of wheat flour.

\subsection{Methods}

Physicochemical and functional characterization of mixtures of wheat flour and brea gum

The water absorption index (WAI) and water solubility index (WSI) can be used as an indicative of starch modification due to a physical or chemical treatment. WAI measures the volume occupied by the starch granule after swelling in excess water, WSI determines the amount of free molecules leached out from the starch granule in excess water (Rodriguez-Sandoval et al., 2014). The WAI and WSI of the wheat flour and flour-BG mixtures were determined by the method of Anderson et al. (1969) and (Burgos \& Armada, 2015). These measurements were done in triplicate.

The pasting properties of the WF, with and without BG at the previously described substitution levels, were obtained using a Rapid Visco Analyzer (RVA-4, Newport Scientific, Warriewood, NSW, Australia). Samples were prepared by mixing of flour $(3.50 \mathrm{~g} \pm 0.50 \mathrm{~g})$ and $25 \mathrm{ml}$ of distilled water. The analysis was conducted based on the American Association of Cereal Chemists (2000) approved method 76-21.01. The heating and cooling cycles were programmed in the following manner: The samples were held at $50^{\circ} \mathrm{C}$ for 1 minute, heated to $95^{\circ} \mathrm{C}$ in 3.42 minutes, held at $95^{\circ} \mathrm{C}$ for 2.70 minutes, cooled to $50{ }^{\circ} \mathrm{C}$ in 3.88 minutes, and held at $50{ }^{\circ} \mathrm{C}$ for 2.00 minutes. The following parameters were analyzed: Pasting temperature $\left({ }^{\circ} \mathrm{C}\right)\left(\mathrm{T}^{\circ} \mathrm{p}\right)$; Peak viscosity (in Brabender Units - BU) (PV); Trough viscosity (in BU) (H); Viscosity at $50^{\circ} \mathrm{C}$ (in BU) (C); Stability or breakdown (in BU), as the difference between $\mathrm{PV}-\mathrm{H}$; Setback (in $\mathrm{BU}$ ) as the difference in viscosity between $\mathrm{C}-\mathrm{H}$. All the determinations were performed in triplicate.

The syneresis (water-holding capacity) of the wheat flour/polysaccharide composite system pasted was determined in the same manner as reported by Funami et al. $(2005,2008)$, after storage at $4{ }^{\circ} \mathrm{C}$ for 24 hours by the weight loss of supernatant as a result of centrifugation. Concentration of wheat flour was fixed at $5 \%$ and the gum was added at the proportions of $0.5 \%$, $1 \%$ and $2 \% \mathrm{w} / \mathrm{w}$ of WF.

Data were presented as means \pm SD of triplicate.

\section{Preparation of breads}

Preliminary experiments (farinographic studies) were performed to establish the proportion of water needed to obtain the doughs (up to optimum consistency of $500 \mathrm{BU}$ ), taking into account that brea gum is a hydrophilic polysaccharide. The bread samples, with and without $B G$ at the previously described substitution levels, were developed using the following proportions of ingredients based on $100 \mathrm{~g}$ of WF: dried yeast $1.6 \%$, salt $2 \%$, fat $2 \%$, and water (quantity calculated according to farinograph water absorption data not shown). Control breads (without BG) were also elaborated.

Ingredients were mixed for ten minutes, kneaded and rolled in a commercial bread maker machine (ATMA easy cook). The dough was fermented at $27^{\circ} \mathrm{C}$, during 95 minutes, and kneaded during 25 minutes; baking was performed at $150^{\circ} \mathrm{C}$ for 60 minutes. Finally, the samples were cooled at room temperature for 120 minutes. Three pieces of each type of bread (twelve loaves) were prepared to analysis.

\section{Evaluation of the influence of brea gum in the technological characteristics of the fresh bread}

Each loaf was characterized by volume (rapeseed displacement) $(\mathrm{V})$, specific volume (SV), specific volume index (specific volume of control loaves were taken as 100 , and the others samples were referred to the control) (SVI) (López \& Goldner, 2015; 
López et al., 2013) and width/height ratio of the central slice (W/H) (López, 2014; Curic et al., 2008). The analysis of the crumb structure was performed by scanning and digitizing the crumb image. Images were taken from the centre of the each bread slice and were captured using an Epson scanner (Epson Stylus CX5900), with a 600 dpi resolution. Crumb cells were analyzed by ImageJ program (Version 1.44p, Wayne Resband, National Institute of Health, USA). The analysis of the crumb structure was performed using the method by López et al. (2013) and Sciarini et al. (2012). Calculations include: total area cells (\%)(TAC), average size of the cells (mm)(ASC), and number of cells per unit area $\left(\mathrm{n}^{\circ} \mathrm{C} / \mathrm{cm}^{2}\right)$. Three replicates for each sample were carried out.

The moisture content was determined in the bread's crumbs, through AOAC official method (method 925.10) (Association of Official Analytical Chemists, 1995). Three replicates for each sample were carried out.

The hardness of the crumb was determined was performed using a QTS 25 Texturometer (Brookfield, USA). A $2.5 \mathrm{~cm}$ thick slice was compressed with a $38.1 \mathrm{~mm}$ acrylic probe up to $40 \%$ deformation, at $120 \mathrm{~mm} / \mathrm{min}$ speed. An instrumental trigger of $5 \mathrm{~g}$ was applied. Three replicates were carried out.

\subsection{Statistical analysis}

One way ANOVA was carried out to assess the differences in functional properties of wheat flour and the physical and chemical characteristics of fresh breads. Multiple means comparisons were carried out by Tukey HSD test at $p<0.05$. Means and standard deviations were also calculated.

Furthermore Pearson's (r) correlations between all variables studied were calculated.

All statistical analysis was performed using Infostat v.2012 $\mathrm{p}^{\circledR}$, registered by Universidad Nacional de Córdoba, Córdoba, Argentina.

\section{Results and discussion}

\subsection{Effect of the brea gum on the functional characteristics of wheat flour}

\section{WAI and WSI}

The WAI and WSI of the wheat flour (WF) and the WF-BG mixtures are reported in Table 1. The water absorption index and water solubility index can be used as an indicative of starch modification due to a physical or chemical treatment (Rodriguez-Sandoval et al., 2014). The WAI measures the volume occupied by the starch granule after swelling in excess of water, and it depends of the content of protein, damage starch and pentosans of the flour, because these are the flour components capable of retaining water. Moreover, these components have major influence on the characteristics of bread (volume, colour, crumb homogeneity, etc.) (Cauvain \& Yung, 2007). The results indicate that the BG would not affect the ability of flour starch to absorb water, which is deduced from the results of the WAI, since this rate was not significantly different $(\mathrm{p}<0.05)$ between control (WF) and samples added with the hydrocolloid.

WSI determines the amount of free molecules leached out from the starch granule in excess of water (Rodriguez-Sandoval et al., 2014). WSI results revealed that the percentage of water soluble solids increased with the addition of BG, and this increase was significant $(\mathrm{p}<0.05)$, indicating that the hydrocolloid is not incorporated into the precipitate, because of its high water solubility $\left(28 \%\right.$ at $\left.25^{\circ} \mathrm{C}\right)$ (Bertuzzi et al., 2012). The gum was almost completely solubilized in the supernatant, indicating the high affinity of the gum for water, and, probably, there is no synergistic interaction between the wheat starch and BG (Funami et al., 2008). To confirm this result, WAI and WSI were also made in the BG, obtaining a WAI $=0.37 \pm 0.03 \mathrm{~g} / \mathrm{g}$, and $\mathrm{WSI}=87.32 \pm 2.45 \%$.

Funami et al. (2008) observed the behaviour of wheat starch in presence of Arabic gum, and found similar results. Their findings were substantiated by a thermodynamic incompatibility between the two polysaccharides and a consequent effect of phase separation.

Moreover, it should be noted that the tendency of hydrocolloid to form bonds with water, could affect the gelatinization, because of the reduced availability of water for starch. This phenomenon would be even more pronounced in systems with lack of water, like bread.

\section{Pasting properties}

The pasting profiles of the wheat flour and the WF-BG mixtures are presented in Table 1. The minimum addition of gum did not introduce significant changes in the pasting temperature $\left(\mathrm{T}^{\circ} \mathrm{p}\right)$, but this parameter was significantly elevated $(\mathrm{p}<0.05)$ by adding BG at $1 \%$ and $2 \%$. This effect could be due to different types of interactions between wheat starch (especially amylose) and the hydroxyl groups of the hydrocolloid (BeMiller, 2011; Song et al., 2008). Funami et al. (2008), exhibited this behaviour may be

Table 1. ANOVA of functional properties of the wheat flour (WF) starch in presence of brea gum.

\begin{tabular}{ccccccc}
\hline & \multicolumn{5}{c}{ Viscosity $(\mathrm{RVA})$} \\
\hline Sample & WAI $(\mathrm{g} / \mathrm{g})$ & WSI $(\%)$ & $\mathrm{T}^{\mathrm{o}} \mathrm{p}^{\mathrm{a})}\left({ }^{\circ} \mathrm{C}\right)$ & PV $^{(\mathrm{b})}(\mathrm{BU})$ & Breakdown $(\mathrm{BU})$ & Setback $(\mathrm{BU})$ \\
\hline WF & $1.67 \pm 0.03^{\mathrm{a}}$ & $4.61 \pm 0.10^{\mathrm{a}}$ & $65.03 \pm 0.36^{\mathrm{a}}$ & $330 \pm 3.00^{\mathrm{c}}$ & $40 \pm 2.50^{\mathrm{b}}$ & $260 \pm 13.00^{\mathrm{a}}$ \\
0.5 & $1.69 \pm 0.04^{\mathrm{a}}$ & $6.14 \pm 0.12^{\mathrm{b}}$ & $65.53 \pm 0.38^{\mathrm{a}}$ & $328 \pm 2.50^{\mathrm{c}}$ & $38 \pm 1.60^{\mathrm{b}}$ & $270 \pm 5.80^{\mathrm{a}}$ \\
1 & $1.68 \pm 0.03^{\mathrm{a}}$ & $6.85 \pm 0.13^{\mathrm{c}}$ & $67.34 \pm 0.49^{\mathrm{b}}$ & $305 \pm 5.80^{\mathrm{b}}$ & $25 \pm 2.70^{\mathrm{a}}$ & $430 \pm 10.50^{\mathrm{c}}$ \\
2 & $1.70 \pm 0.02^{\mathrm{a}}$ & $7.37 \pm 0.15^{\mathrm{d}}$ & $69.03 \pm 0.23^{\mathrm{c}}$ & $290 \pm 5.00^{\mathrm{a}}$ & $10 \pm 2.10^{\mathrm{a}}$ & $455 \pm 18.00^{\mathrm{d}}$ \\
\hline
\end{tabular}

Means \pm standard deviations $(n=3)$. Values in the columns followed by the same letter are not significantly different (p<0.05), according to Tukey's test. ${ }^{(a)}$ Pasting temperature. ${ }^{(b)}$ Peak viscosity. The BG reduced the availability of water for starch, so higher temperature was needed to begin the gelatinization. This effect was accentuated by increase in the amount of BG added to the flour. 
due to a barrier effect of the hydrocolloid, that is surrounding the starch granule, retarding the water and temperature effect (gelatinization). This phenomenon was also observed by Bárcenas et al. (2009), who added different concentrations of gum Arabic to the wheat flour, and Rojas et al. (1999), by incorporating HPMC and pectin (0.5\%), who reported a slight increase in $\mathrm{T}^{\circ} \mathrm{p}$ or pasting. High positive correlation between $\mathrm{T}^{\circ} \mathrm{p}$ and WSI $(\mathrm{r}=0.89 ; \mathrm{p}<0.001)$ was observed.

The peak viscosity $(\mathrm{PV})$ was significantly lower $(\mathrm{p}<0.05)$ in the flours added with $1 \%$ and $2 \%$ of hydrocolloid. The same behaviour was observed by Bárcenas et al. (2009), Funami et al. (2008) and Stephen \& Churms (1995) when they studied systems of wheat flour: gum Arabic. The authors argued that the effect would be justified in that the low apparent viscosity of the hydrocolloid (clearly Newtonian behavior), due to its spherical molecular configuration (Stephen \& Churms, 1995), which would help to lubricate the system without stickiness (i.e. viscosity) (Funami et al., 2008). These variations also may be explained by a decrease in leached amylose, due to a lower gelatinization of the starch granules. The differences were not significant between the control and the sample with the lowest addition (0.5\%). A perfect negative correlation between PV and $\mathrm{T}^{\circ} \mathrm{p}(\mathrm{r}=-1 ; \mathrm{p}<0.001)$ was observed.

The lower value of PV resulted in an increased of stability or Breakdown (Table 1) (PV vs. Breakdown $\mathrm{r}=0.99 ; \mathrm{p}<0.001$ ). This would be justified by the formation of a polysaccharide "barrier" or "film" (Funami et al., 2008). The presence of the gum probably prevents abrasion between starch granules, therefore, causes less amount of leached amylose (Funami et al., 2008). Thereby, in the samples with added BG, the starch would have greater resistance to heat and shear (more stable) than the control sample. Also, a perfect negative correlation between Breakdown and $\mathrm{T}^{\circ} \mathrm{p}(\mathrm{r}=-1 ; \mathrm{p}<0.001)$ was observed.

During the cooling stage occurs the retrogradation of amylose chains (leached outside the starch granules during cooking). The retrogradation cause an increase of viscosity (setback) (Burgos \& Armada, 2015): the transition of amylose, including lipids, could be responsible for the increase in viscosity and is responsible of the firming of bread crumb during the first hours after baking (Rojas et al., 1999). Thus, it is convenient to have the addition of additives and/or ingredients that promote a reduction of the setback, and in consequence, a delay of the firming crumb (Rojas et al., 1999). In the present study, Setback values (Table 1 ) were increased in the presence of $1 \%$ and $2 \%$ of $\mathrm{BG}$, and the difference whit the control and $0.5 \%$ formulation was significant $(\mathrm{p}<0.05)$. High positive correlations between Setback vs. WSI $(\mathrm{r}=0.87 ; \mathrm{p}<0.01)$ and vs. $\mathrm{T}^{\circ} \mathrm{p}(\mathrm{r}=0.96 ; \mathrm{p}<0.001)$ were observed. In addition, high negative correlations were observed between Setback vs. PV $(\mathrm{r}=-0.97 ; \mathrm{p}<0.001)$ and vs. Breakdown $(\mathrm{r}=-0.94 ; \mathrm{p}<0.001)$. This effect can be explained by a phase separation process, related to a phenomenon of incompatibility between the two polymers (starch and gum), which in fact, are not linked (Funami et al., 2008). Stated another way, both polysaccharides presented a "mutual exclusion", given by the thermodynamic incompatibility, resulting in increased syneresis of the composite system (Funami et al., 2008). Again, it is unlikely that BG associates with amylose. That is, the polysaccharide added promotes starch retrogradation at an early stage of short-term retrogradation, where amylose gelation plays a dominant role, without any molecular associations that contribute to structural ordering.

The addition of the polysaccharide, in any of the studied proportions, increased the syneresis of the composite system $(\mathrm{p}<0.05)$ upon storage at $4^{\circ} \mathrm{C}$ for 24 hours (Figure 1). This would correlate with the decrease in the value of PV (syneresis vs. PV $r=-0.96 ; p<0.001$ ) (Table 1) and the least amount of leached amylose, and was opposite to the results presented by Rojas et al. (1999) for alginate, k-carrageenan and xanthan. High positive correlations between syneresis vs. Setback $(r=0.99 ; p<0.001)$ and vs. $\mathrm{T}^{\circ} \mathrm{p}(\mathrm{r}=0.96 ; \mathrm{p}<0.001)$ were observed. In addition, high negative correlations between syneresis vs. PV $(r=-0.96$; $\mathrm{p}<0.001)$ and vs. Breakdown $(\mathrm{r}=-0.92 ; \mathrm{p}<0.001)$ were also observed. The increase in syneresis, or the reduced water holding capacity of the composite system, was due to the incomplete hydration of the starch granules or swelling. As is know, swelling involves the melting of crystalline structures and the leaching of amylose (and some amylopectin fractions) upon heating of starch in an aqueous environment. Similar results were informed by Funami et al. (2008), when studied the behaviour of wheat starch in presence of gum Arabic or soy-bean soluble polysaccharide.

Hydrocolloids immobilize water molecules, resulting in an increase of the effective starch concentration (Bárcenas et al., 2009). However, numerous studies have described the effect of different hydrocolloids on starch gelatinization and retrogradation (BeMiller, 2011; Bárcenas et al., 2009; Funami et al., 2008, 2005; Rosell et al., 2001; Rojas et al., 1999; Davidou et al., 1996), showing the unpredictable behaviour of each gum, which is highly dependent on their structure, environment conditions and concentration (Bárcenas et al., 2009). Nevertheless, the mechanism of how these additives influence starch retrogradation is not completely understood.

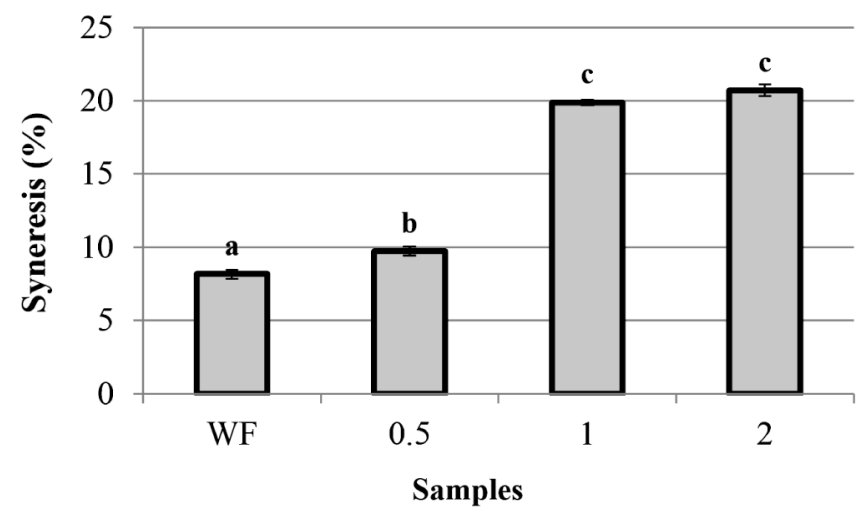

Figure 1. Syneresis of wheat flour: brea gum composite systems. Values in the bars followed by the same letter are not significantly different ( $\mathrm{p}<0.05)$, according to Tukey's test. WF: wheat flour; WF: wheat flour bread; $0.5,1,2$ : wheat flour added with $0.5 \%, 1 \%$ and $2 \%$ respectively of brea gum (flour basis). 


\subsection{Evaluation of the influence of brea gum in the technological characteristics of the fresh bread}

Physicochemical parameters

Table 2 summarizes the data related to the physicochemical analysis of fresh breads.

The volume of the four loaves was not significantly different. The presence of BG did not improve the volume in fresh bread, probably because it is not a gum with surface active properties such as HPMC -which forms an interfacial film at the boundaries of gas cells that possibly provides stability in the cells during expansion - (Hager \& Ardent, 2013). Contrary to alginates, BG not reduced the bread volume (Rosell et al., 2001).

However, the loaves added with greater amount of BG had lower specific volumes $(\mathrm{p}<0.05)$. This effect was due to that the breads with $1 \%$ and $2 \%$ of hydrocolloid had higher weight than the others samples (data not shown). Consequently, the SVI was lower $(\mathrm{p}<0.05)$ for the breads with higher amount of gum. Is important to note the correlation between PV and VE $(\mathrm{r}=0.98 ; \mathrm{p}<0.05)$ : breads with the highest specific volume were those with lower proportions of BG added, i.e., those with a higher degree of starch gelatinization (highest PV).

Other authors reported that some hydrocolloids such as xanthan gum, guar gum, locust bean gum and HPMC, produced an increase of the SV (Mandala et al., 2007; Bárcenas \& Rosell, 2005; Rosell et al., 2001). In fresh breads, increase in specific volume of by adding these hydrocolloids was attributed to that gums give some stability to the interface during dough proofing system, conferring additional strength to the gas cells through baking (Mandala et al., 2007; Rosell et al., 2001).

The $\mathrm{W} / \mathrm{H}$ ratio was not significant different $(\mathrm{p}<0.05)$ between the samples, i.e., the shape of the slice was not affected by the proportion of BG. A high positive correlation between $\mathrm{V}$ and $\mathrm{W} / \mathrm{H}$ ratio was observed $(\mathrm{r}=0.99 ; \mathrm{p}<0.001)$.

In addition, the explanation for these results was related to that found in the crumb structure (Table 2). Breads with $1 \%$ and $2 \%$ of BG presented smaller alveoli $(\mathrm{p}<0.05)$, for which they were found in greater numbers per unit area, compared to control bread and that added with $0.5 \%$ of hydrocolloid. This resulted in more compact and less airy crumbs. The fraction of the area occupied by air spaces (\%) or TAC, was greater for control and $0.5 \%$ of BG breads ( $p<0.05)$, respect to the others samples. This result was associated to a more open structure for the first ones crumbs. The average size of cells (ASC) was lower $(\mathrm{p}<0.05)$ in the breads with $1 \%$ and $2 \%$ of hydrocolloid, and the number of cells per unit area $\left(\mathrm{n}^{\circ} \mathrm{C} / \mathrm{cm}^{2}\right)$ was significant higher $(\mathrm{p}<0.05)$ for the same samples respect to the control bread and the crumb with $0.5 \%$ of BG. High correlations were observed between ASC and $\mathrm{n}^{\circ} \mathrm{C} / \mathrm{cm}^{2}$ and the physical parameters (ASC vs: $\mathrm{n}^{\circ} \mathrm{C} / \mathrm{cm}^{2}:-0.98 ; \mathrm{p}<0.001$ - ASC vs. Volume; $\mathrm{r}=0.97 ; \mathrm{p}<0.001$ - ASC vs. Specific volume: $r=0.97 ; \mathrm{p}<0.001$ - ASC vs. Specific volume index: $\mathrm{r}=0.96 ; \mathrm{p}<0.001-$ ASC vs. W/H: $\mathrm{r}=-0.99$; $\mathrm{p}<0.001-\mathrm{n}^{\circ} \mathrm{C} / \mathrm{cm}^{2}$ vs. Volume: $\mathrm{r}=-0.95 ; \mathrm{p}<0.001-\mathrm{n}^{\circ} \mathrm{C} / \mathrm{cm}^{2}$ vs. Specific volume: $\mathrm{r}=-0.98 ; \mathrm{p}<0.001-\mathrm{n}^{\circ} \mathrm{C} / \mathrm{cm}^{2}$ vs. Specific volume index: $\mathrm{r}=-0.99 ; \mathrm{p}<0.001-\mathrm{n}^{\circ} \mathrm{C} / \mathrm{cm}^{2}$ vs. $\mathrm{W} / \mathrm{H}: \mathrm{r}=0.99$; $\mathrm{p}<0.001)$. The characteristics of the crumb were highly correlated with physical parameters, but also with pasting properties and syneresis: SV was positively associated with $\mathrm{PV}(\mathrm{r}=0.97$; $\mathrm{p}<0.05)$ and negatively with the Setback $(\mathrm{r}=-0.98 ; \mathrm{p}<0.05)$ and syneresis $(\mathrm{r}=-0.97 ; \mathrm{p}<0.05)$. The adding of $\mathrm{BG}$ at $1 \%$ and $2 \%$ level caused a fall of the PV (generated by a decrease in starch gelatinization) that was manifested in the SV and crumb structure. In effect, bread crumbs with higher proportions of hydrocolloid were denser and less aerated than the control and $0.5 \%$ BG samples.

It must be emphasized that the addition of the hydrocolloid to $0.5 \%$ did not affect the physical quality or crumb structure.

Next, Table 3 shows the results relating to moisture and hardness of the crumbs with different proportions of BG.

As can be seen, the moisture of the samples at $1 \%$ and $2 \%$ of gum resulted higher than the control and $0.5 \% \mathrm{BG}$ bread, which was expected due to an increase of the quantity of water necessary for the formation of the dough, (up to optimum consistency of 500 Brabender units - data not shown). This indicates the water absorption of the dough with added BG was major. This effect was due to the water retention ability of this polymer resulting from the hydrophilic nature of most of the gums (Guarda et al., 2004; Gurkin, 2002; Collar et al., 1999). Perhaps this behaviour demonstrates that during cooking, the hydrocolloid forms a network that could act as a barrier to the diffusion of gases, which in turn would reduce vapour losses, resulting in higher moisture content of crumb bread (López et al., 2013). Similar behaviour was reported by Bárcenas \& Rosell (2005) for breads with added HPMC, and López et al. (2013). The moisture showed high correlation with physical parameters and crumb structure (moisture vs. SV: $\mathrm{r}=-1 ; \mathrm{p}<0.01$; vs. ASC: $\mathrm{r}=-0.93$; $\mathrm{p}<0.05$; vs. $\left.\mathrm{n}^{\circ} \mathrm{C} / \mathrm{cm}^{2}: \mathrm{r}=0.91 ; \mathrm{p}<0.05\right)$. In general, having greater moisture in the dough more steam is generated, which would increase the volume and expand the alveolus. On the contrary, in this study it was observed that the higher moisture was associated with loss of quality.

Table 2. ANOVA of physical characteristics of breads made with and without addition of brea gum.

\begin{tabular}{cccccccc}
\hline Sample & Volume $\left(\mathrm{cm}^{3}\right)$ & $\begin{array}{c}\mathrm{SV}^{(\mathrm{a})} \\
\left(\mathrm{cm}^{3} / \mathrm{g}\right)\end{array}$ & $\begin{array}{c}\text { SVI } \\
(\%)\end{array}$ & W/H & $\begin{array}{c}\mathrm{ASC}^{(\mathrm{c})} \\
(\mathrm{mm})\end{array}$ & $\begin{array}{c}\mathrm{TAC}^{(\mathrm{e})} \\
(\%)\end{array}$ \\
\hline WF & $732.00 \pm 1,41 \mathrm{a}$ & $3.18 \pm 0.03 \mathrm{~b}$ & $100 \pm 0.00 \mathrm{~b}$ & $1.28 \pm 0.03 \mathrm{a}$ & $4.03 \pm 0.06 \mathrm{~b}$ & $7.73 \pm 0.08 \mathrm{a}$ & $40.55 \pm 0.59 \mathrm{~b}$ \\
0.5 & $732.50 \pm 0.71 \mathrm{a}$ & $3.13 \pm 0.02 \mathrm{~b}$ & $98.57 \pm 0.51 \mathrm{~b}$ & $1.26 \pm 0.02 \mathrm{a}$ & $4.01 \pm 0.13 \mathrm{~b}$ & $7.73 \pm 0.19 \mathrm{a}$ & $40.79 \pm 0.28 \mathrm{~b}$ \\
1 & $731.50 \pm 2.12 \mathrm{a}$ & $3.04 \pm 0.02 \mathrm{a}$ & $95.78 \pm 0.56 \mathrm{a}$ & $1.25 \pm 0.01 \mathrm{a}$ & $3.22 \pm 0.04 \mathrm{a}$ & $12.02 \pm 0.25 \mathrm{~b}$ & $35.49 \pm 0.64 \mathrm{a}$ \\
2 & $732.00 \pm 1.41 \mathrm{a}$ & $3.00 \pm 0.01 \mathrm{a}$ & $94.47 \pm 0.37 \mathrm{a}$ & $1.28 \pm 0.01 \mathrm{a}$ & $3.21 \pm 0.05 \mathrm{a}$ & $11.72 \pm 0.19 \mathrm{~b}$ & $35.07 \pm 0.04 \mathrm{a}$ \\
\hline
\end{tabular}

Means \pm standard deviations $(n=3)$. Values in the columns followed by the same letter are not significantly different ( $\mathrm{p}<0.05)$, according to Tukey's test. (a) Specific Volume index.

(b) width/height ratio. ${ }^{\left({ }^{(c)}\right.}$ Average Size of the cell. ${ }^{(d)}$ number of alveoli per unit area. ${ }^{\left({ }^{(}\right)}$Total Area Cells. 
Table 3. ANOVA for moisture and hardness of the crumbs added with different levels of brea gum.

\begin{tabular}{ccl}
\hline Brea gum addition & $\begin{array}{c}\text { Moisture } \\
\mathrm{g} / 100 \mathrm{~g}\end{array}$ & $\begin{array}{c}\text { Hardness } \\
\mathrm{g}\end{array}$ \\
\hline WF & $41.19 \pm 0.03 \mathrm{a}$ & $220 \pm 12 \mathrm{a}$ \\
0.5 & $41.21 \pm 0.02 \mathrm{a}$ & $225 \pm 3 \mathrm{a}$ \\
1 & $42.95 \pm 0.01 \mathrm{~b}$ & $300 \pm 11 \mathrm{~b}$ \\
2 & $43.65 \pm 0.02 \mathrm{c}$ & $340 \pm 6 \mathrm{c}$ \\
\hline
\end{tabular}

Means \pm standard deviations $(n=3)$. Values in the columns followed by the same letter are not significantly different $(p<0.05)$, according to Tukey's test.

This can be explained in that high concentrations of gum caused an increase of moisture in crumb but also a decline of water available for wheat starch (low viscosity peak), which caused a decrease in gelatinization and amylose leaching. Amylose contained in the starch granules, diffuses rapidly, gelatinized and retrograded, favouring the formation of the bread crumb structure. For this reasons the high moisture in crumb was correlated with low quality.

For hardness (Table 3), breads with BG 1\% and 2\% were significantly harder than the control and the sample added to $0.5 \%$. The addition of BG increased the hardness of the bread crumb which could be a consequence of the thickening effect on the crumb walls surrounding air spaces as proposed by López et al. (2013), Guarda et al. (2004) and Rosell et al. (2001) for others hydrocolloids.

Other explanation to those results was that the hardest crumbs were the less aerated ones. This was corroborated by the results observed in the Pearson's correlations between hardness and SV $(\mathrm{r}=-0.97 ; \mathrm{p}<0.05)$, ASC $(\mathrm{r}=-0.96 ; \mathrm{p}<0.05), \mathrm{n}^{\circ} \mathrm{C} / \mathrm{cm}^{2}$ $(\mathrm{r}=0.94 ; \mathrm{p}<0.05)$, and TAC $(\mathrm{r}=-0.97 ; \mathrm{p}<0.05)$.

Is important to highlight that in the present study a high and positive relationship between hardness and moisture was observed $(r=0.97 ; p<0.05)$, although in the literature is generally reported an inverse relationship between these parameters (Sciarini et al., 2012).

\section{Conclusion}

The highest levels of brea gum (1\% y 2\%), modified the pasting parameters of wheat flour: the peak viscosity (PV) was significantly lower $(\mathrm{p}<0.05)$ than the others samples, and the stability and setback of the past were increased. These variations may be explained by a decrease in leached amylose, due to a lower gelatinization of the starch granules, caused by a competition for water between the hydrocolloid and starch. These changes in the behaviour of starch influenced the bread quality. The loaves added with $1 \%$ and $2 \%$ of BG presented smaller alveoli $(\mathrm{p}<0.05)$, for which it were found in greater numbers per unit area, compared to control bread and that added with $0.5 \%$ of hydrocolloid. This resulted in more compact, hard and less airy crumbs. Furthermore, the moisture of the samples at $1 \%$ and $2 \%$ of added gum was higher than the control and $0.5 \%$ BG bread. In these samples, high moisture was associated with loss of quality. However, it should be noted that incorporation of BG $0.5 \%$ did not affect the physical parameters and the crumb structure, but increased moisture of bread, so this concentration would be most recommended for baking, since higher humidity could favour the shelf- life of the product.

\section{Acknowledgements}

The authors wish to thank Professor Mark Shaw for his invaluable help in the correction of language.

\section{References}

American Association of Cereal Chemists - AACC. (2000). Approved methods of the AACC (10th ed.). St. Paul: AACC.

Anderson, R. A., Conway, H. F., Pfeiffer, U. F., \& Griffin, E. L. (1969). Gelatinization of corn grits by roll and extrusion-cooking. Cereal Science Today, 14, 1-4.

Armero, E., \& Collar, C. (1996). Antistaling additive effects on fresh wheat bread quality. Food Science \& Technology International, 2(5), 323-333. http://dx.doi.org/10.1177/108201329600200506.

Association of Official Analytical Chemists - AOAC. (1995). Official methods of analysis of the AOAC International (Vol. 2). Washington, DC: AOAC.

Bárcenas, M. E., \& Rosell, C. M. (2005). Effect of HPMC addition on the microstructure, quality and aging of wheat bread. Food Hydrocolloids, 19(6), 1037-1043. http://dx.doi.org/10.1016/j.foodhyd.2005.01.005.

Bárcenas, M. E., O-Keller, J., \& Rosell, C. M. (2009). Influence of different hydrocolloids on major wheat dough components (gluten and starch). Journal of Food Engineering, 94(3), 241-247. http:// dx.doi.org/10.1016/j.jfoodeng.2009.03.012.

BeMiller, J. N. (2011). Pasting, paste, and gel properties of starchhydrocolloid combinations. Carbohydrate Polymers, 86(2), 386-423. http://dx.doi.org/10.1016/j.carbpol.2011.05.064.

Bertuzzi, M. A., Slavutsky, A. M., \& Armada, M. (2012). Physicochemical characterization of the hydrocolloid from Brea tree (Cercidium praecox). International Journal of Food Science \& Technology, 47(4), 776-782. http://dx.doi.org/10.1111/j.1365-2621.2011.02907.x.

Bowles, S., \& Demiate, I. M. (2006). Physicochemical characterization of the soymilk by product - okara. Food Science and Technology (Campinas.), 26(3), 652-659. http://dx.doi.org/10.1590/S010120612006000300026.

Burgos, V. E., \& Armada, M. (2015). Characterization and nutritional value of precooked products of kiwicha grains (Amaranthus caudatus). Food Science and Technology (Campinas.), 35(3), 531-538. http:// dx.doi.org/10.1590/1678-457X.6767.

Cauvain, S., \& Yung, L. (2007). Fabricación de pan. 1st reimp. Zaragoza: Acribia.

Cerezo, A., Stacey, M., \& Webber, J. (1969). Some structural studies of brea gum (an exudate from Cercidium australe Jonhst). Carbohydrate Research, 9(4), 505-517. http://dx.doi.org/10.1016/ S0008-6215(00)80035-X.

Collar, C., Andreu, P., Martínez, J. C., \& Armero, E. (1999). Optimization of hydrocolloid addition to improve wheat bread dough functionality: A response surface methodology study. Food Hydrocolloids, 13(6), 467-475. http://dx.doi.org/10.1016/S0268-005X(99)00030-2.

Curic, D., Novotni, D., Skevin, D., Rosell, C., Collar, C., LeBail, A., Colic-Baric, I., \& Gabric, D. (2008). Design of a quality index for the objetive evaluation of bread quality: Application to wheat bread using selected bake off technology for bread making. Food Research International, 41(7), 714-719. http://dx.doi.org/10.1016/j. foodres.2008.05.006. 
Davidou, S., Le Meste, M., Debever, E., \& Bekaert, D. (1996). A contribution to the study of staling 400 of white bread: effect of water and hydrocolloid. Food Hydrocolloids, 10(4), 375-383. http:// dx.doi.org/10.1016/S0268-005X(96)80016-6.

De Pinto, G., Rodriguez, O., Martinez, M., \& Rivas, C. (1993). Composition of Cercidium praecox gum exudates. Biochemical Systematics and Ecology, 21(2), 297-300. http://dx.doi.org/10.1016/03051978(93)90048-V.

Dziezak, J. D. (1991). A focus on gums. Food Technology, 45(3), 115-132.

Funami, T., Kataoka, Y., Omoto, T., Goto, Y., Asai, I., \& Nishinari, K. (2005). Effects of non-ionic polysaccharides on the gelatinization and retrogradation behavior of wheat starch. Food Hydrocolloids, 19(1), 1-13. http://dx.doi.org/10.1016/j.foodhyd.2004.04.024.

Funami, T., Nakauma, M., Noda, S., Ishihara, S., Asai, I., Inouchi, N., \& Nishinari, K. (2008). Effects of some anionic polysaccharides on the gelatinzation and retrogradation behaviors of wheat starch: Soybean-soluble polysaccharide and gum arabic. Food Hydrocolloids, 22(8), 1528-1540. http://dx.doi.org/10.1016/j.foodhyd.2007.10.008.

Guarda, A., Rosell, C. M., Benedito, C., \& Galotto, M. J. (2004). Different hydrocolloids as bread improvers and antistaling agents. Food Hydrocolloids, 18(2), 241-247. http://dx.doi.org/10.1016/ S0268-005X(03)00080-8.

Gurkin, S. (2002). Hydrocolloids-Ingredients that add flexibility to tortilla processing. Cereal Foods World, 47(2), 41-43.

Hager, A.-S., \& Ardent, E. K. (2013). Influence of hidroxopropilmetilcelulose (HPMC), xanthan gum and their combination on loaf specific volume, crumb hardness and crumb grain characteristics of gluten-free breads based on rice, maize, teff and buckwheat. Food Hydrocolloids, 32(1), 195-203. http://dx.doi.org/10.1016/j.foodhyd.2012.12.021.

Kurek, M. A., Wyrwisz, J., Piwińska, M., \& Wierzbicka, A. (2015). Influence of the wheat flour extraction degree in the quality of bread made with high proportions of $\beta$-glucan. Food Science and Technology (Campinas.), 35(2), 273-278.

López, E. P. (2014). Influence of the addition of lupine protein isolate on the protein and technological characteristics of dough and fresh bread with added Brea Gum. Food Science and Technology (Campinas.), 34(1), 195-203. http://dx.doi.org/10.1590/S0101-20612014005000016.

López, E. P., \& Goldner, M. C. (2015). Influence of storage time for the acceptability of bread formulated with lupine protein isolate and added brea gum. $L W T$-. Food Science and Technology (Campinas.), 64(2), 1171-1178.

López, E., Pérez, G., Erramouspe, P. L. J., \& Cuevas, C. (2013). Effect of Brea Gum on the characteristics of wheat bread at different storage times. Food Science and Technology (Campinas.), 33(4), 745-752. http://dx.doi.org/10.1590/S0101-20612013000400021. [Campinas]
Mandala, I., Kapetanakou, A., \& Kostaropoulos, A. (2008). Physical properties of breads containing hydrocolloids stored at low temperature: II-Effect of freezing. Food Hydrocolloids, 22(8), 1443-1451. http:// dx.doi.org/10.1016/j.foodhyd.2007.09.003.

Mandala, I., Karabela, D., \& Kostaropoulos, A. (2007). Physical properties of breads containing hydrocolloids stored at low temperature. I. Effect of chilling. Food Hydrocolloids, 21(8), 1397-1406. http:// dx.doi.org/10.1016/j.foodhyd.2006.11.007.

Polaki, A., Xasapis, P., Fasseas, C., Yanniotis, S., \& Mandala, I. (2010). Fiber and hydrocolloids content affect the microstructural and sensory characteristics of fresh and stored bread. Journal of Food Engineering, 97(1), 1-7. http://dx.doi.org/10.1016/j.jfoodeng.2009.04.031.

Rodriguez-Sandoval, E., Franco, C. M. L., \& Manjarres-Pinzon, K. (2014). Effect of fructooligosaccharides on the physicochemical properties of sour cassava starch and baking quality of gluten-free cheese bread. Stärke, 66(7), 678-684. http://dx.doi.org/10.1002/ star.201300233.

Rojas, J. A., Rosell, C. M., \& Benedito de Barber, C. (1999). Pasting properties of different wheat flour-hydrocolloid systems. Food Hydrocolloids, 13(1), 27-33. http://dx.doi.org/10.1016/S0268005X(98)00066-6.

Rosell, C. M., Rojas, J. A., \& Benedito de Barber, C. (2001). Influence of hydrocolloids on dough rheology and bread quality. Food Hydrocolloids, 15(1), 75-81. http://dx.doi.org/10.1016/S0268-005X(00)00054-0.

Sciarini, L., Ribotta, P., León, A., \& Pérez, G. (2012). Incorporation of several additives 443 into gluten-free breads: Effect on dough properties and bread quality. Journal of Food Engineering, 111(4), 590-597. http://dx.doi.org/10.1016/j.jfoodeng.2012.03.011.

Škara, N., Novotni, D., Čukelj, N., Smerdel, B., \& Ćurić, D. (2013). Combined effects of inulin, pectin and guar gum on the quality and stability of partially baked frozen bread. Food Hydrocolloids, 30(1), 428-436. http://dx.doi.org/10.1016/j.foodhyd.2012.06.005.

Song, J.-Y., Kim, Y.-C., \& Shin, M. (2008). Textural properties and structures of wheat and maize starch-gum mixed gels during storage. Food Science and Biotechnology, 17, 20-25.

Stephen, A. M., \& Churms, S. C. (1995). Gums and mucilages. In A. M. Stephen (Ed.), Food polysaccharides and their applications (pp. 377-440). New York: Marcel Dekker, Inc.

von Müller, A. R., López, C. B., Eynard, A. R., \& Guzmán, C. A. (2009). Subchronic toxicological evaluation of brea gum (Parkinsonia praecox) as a food additive in BALB/c mice. Drug and Chemical Toxicology, 32(4), 307-311. http://dx.doi.org/10.1080/01480540902976903. PMid:19793021. 